\section{Scientific Nomenclature}

THE Kakapo or Night Kaka of New Zealand, Strigops habrootilus, described in NATURE at p. r9o as the ground parrot, is called the owl-parrot by $\mathrm{Mr}$. Wood in the current number of the "Student." So long as both names are given there is no confusion, but it is otherwise if a full description is omitted; and I have to suggest that it is very desirable to adopt a uniform usage upon all occasions.

It is curious to notice the analogy between the words psittakos of ancierit Greece and the Kaka ot aboriginal New Zealand; as the Greek word has been traced to a Sanscrit origin it would seem that the New Zealand word must have originated since the Aryan descent upon India.

A. $\mathrm{H}$.

\section{NATURAL SCIENCE AT CAMBRIDGE}

THE following Lectures in Natural Sciences will be delivered at Trinity, St. John's and Sidney Sussex Colleges during the Lent Term, 187ı. On Electricity (for the Natural Sciences Tripos,) by Mr. Trotter, Trinity College, in lecture room No. Ir. on Tuesdays, Thursd rys, Saturdays, at Io, commencing February 4. On Electricity and Magnetism (for the special examination for the B.A. degree), by Mr. Trotter, Trinity College, in lecture room No. II, on Mondays, Wednesdays, Fridays, at Io, commencing Wednesday, February I. On Chemistry, by Mr. Main, St. John's College, on Tuesdays, Thursdays, Saturdays, at I2, in St. John's College, Laboratory, commencing Tuesday, January 3I. Instruction in Practical Chemistry will also be given. On Geology, by Mr. Bonney, St. John's College : (I) Palæontology, on Wednesdays and Fridays, at 9, commencing Wednesday, February I ; (2) Lyell's Principles of Geology, on Tuesdays and Thursdays, at 9, commencing Tuesday, January 31 ; (3) Elementary Lectures on Tuesdays and Thursdays at II, commencing Tuesday, January $3 \mathbf{I}$. On Structural and Morphological Botany, by Mr. Hicks Sidney College, in the College Laboratory, on Mondays, Wednesdays, Fridays, at Io, commencing Wednesday, February 1. On Physiology, by the Trinity Prælector of Physiology (Dr. M. Foster), at the New Museums, on Wednesdays, Thursdays, Fridays, at I I, beginning Wednesday, February I. The Physiological Laboratory will be open for pratical instruction in Physiology daily.

It may be remembered that a year ago we pointed out some defects in the prospectus issued for the intercollegiate teaching of Natural Science by Trinity and St. John's Colleges, Cambridge. We are glad to find that, as will be found from the above statement, these have been rectified, and that by the appointment by Trinity College of Dr. Michael Foster as Prælector of Physiology, and by combining with Sidney College, and so availing themselves of the services of Mr. Hicks of that College, who obtained the first place in the Natural Sciences Tripos, as lecturer on Structural and Morphological Botany, the staff has been greatly strengthened, and the prospect of thorough teaching proportionately increased. The lectures are open to members of the other colleges upon payment of a small fee.

\section{OCEANIC VERTEBRATES*}

$\mathrm{SO}$ far as concerns their distribution, animals may be divided into two classes, the tenants of the land and fresh waters, and the inbabitants of the ocean. In the one case their boundaries depend. upon the form and extent of continents past and present; on the other, upon the corresponding limits of the ocean.

Little enough is as yet known with certainty about the general distribution of terrestrial animals; about those of

* Note intorno al'a distribuzione, della Fauna Vertebrata nell'oceano, presse durante un viagk io intorno al Globo, $1865-68$, dal Professore Enrico Hillyer Gigtioli. Firenze, 1870, 8 vo, o6 pp. the ocean we are still more ignorant. It is, therefore, with great pleasure that we have received Prof. Giglioli's notes on the vertebrated animals which wer: met with during the voyage of the Italian frigate Magenta round the world. The scientific command of this expedition was originally entrusted to Prof. Philippi of Turin. Upon his lamented death at Hong Kong, the author of the present treatise, we believe, succeeded to the post, and is now busily engaged in working out the results obtained by the expedition in every branch of natural history. The present memoir, although founded on observations made during the voyage of the Magenta, seems to be only incidentally connected therewith, and to have been prepared with reference to a competition for the Chair of Zoology and Comparative Anatomy at the Royal Institute of Practical Studies in Florence.

Professor Giglioli commences his remarks by treating of the oceanic fishes met with during his voyages. Although it is quite true, according to the popular idea, that the sea is full of fishes, it must be recollected that those that inhabit the mid-ocean are quite distinct from those that swarm round the coasts, and are not nearly so numerous. At the same time, many of them are remarkable for their brilliant colour, and are otherwise of special interest. It is difficult, says Professor Giglioli, to describe the beauty of the Coryphana hippuris when first taken from the water: a thousand different tints of deep azure and golden yellow sparkle over its body, which, however, fade upon death with surprising celerity. Other oceanic fishes are the large Thersytes, various species of Tunny, the wellknown Pilot fish (Naucrates), and the Echeneis, concerning which such marvellous tales are told by ancient writers. But, perhaps, the most attractive of all the group to the oceanic traveller are the flying fishes (Exocetus). Of this genus six species were met with during the voyage of the Magenta, each appearing to have a peculiar district of the ocean assigned to its range.

Of the class of reptiles which Professor Giglioli next speaks of, two orders only have oceanic representativesnamely, the Ophidia and Testudinata. Of the seasnakes three species were met with belonging to the genera Hydrophis and Pelamis. This peculiar family of serpents was formerly supposed to be confined to the Inoian Ocean ; but it has of late years been discovered to extend its range over the Pacific, even up to the Gulf of Panama. Of the marine Turtles likewise three species, all well known, were observed.

The class of birc's, which follows third in Prof. Giglioli's memoir, is much better represented on the so-called "desolate" ocean. Members of four large families of this class frequent the seas traversed by the Magenta, which were chiefly those belongirg to the southern hemisphere. These are the Penguins (Spheniscidd $)$, the Petrels (Pro ellariida), the Gulls (Laviaa), and the Pelicans (Pelicanida). A fifth great oceanic family, the Awks (Alcidce), replaces the penguins in the Arctic Seas, and was not met with by Prof. Giglioli. The most abundant of all oceanic birds are, of course, the petrels and albatrosses, of the family Procellariidæ, many of which pass by far the greater part of their lives in mid-ocean. Upwards of forty species of this group are enumerated as having been encountered during the circumnavigation of the Magenta, amongst which are several supposed to be new to science, and which are provided with new names accordingly.

The mammals of the orean, which the present memoir lastly treats of, belong to three very different orders: the Cetaceans, Seals, and Sirenians. Of these the first alone pass their whole existence in the salt sea. All the marine Carnivores, so far as we know, habitually reso:t to land, or at all events to ice, which in polar regions serves the same purpose, and of the few existing members of the Sirenia, one at least is rather an inhabitant of fresh water than of salt. Prof. Gigioli's observations are chiefly confinied to the Cetaceans, of which thirteen or fourteen 
species were met with in various parts of the ocean traversed by the Magenta.

At the end of his memoir, Professor Giglioli gives a kind of journal of his voyage, containing the approximate latitude and longitude of the Magenta upon each day of her circumnavigation, and the various species of vertebrates observed or obtained, in parallel columns. Further assistance in tracing the distribution of oceanic life is afforded by the concluding chart, in which the track of the vessel is exactly delineated, and the names of the principal animals met with on each spot are likewise given.

It will be thus seen that even an oceanic voyage round the world, without counting the foreign lands touched upon, affords ample opportunities for the student of nature who has the use of his hands and eyes. In sending a single frigate on such a voyage, the poverty-stricken government of Italy does not hesitate to put on board a band of scientific observers. Does Mr. Childers do the same, when he sends his flying squadron round the world composed of the largest and most expensive ships which wealthy England can produce? We are ashamed to say he does not. Any application, even, for a free passage for a naturalist on such an occasion, would receive the stereotyped refusal, and the answer that "my lords" had no funds to devote to such purposes, and no space to spare.
P. L. S.

\section{EARTHQUAKES AT FIUME DURING THE $Y E A R \quad 1870$}

THE following list of earthquakes at Fiume during the year 1870 is sent by a correspondent at that town, to whom it was furnished by Prof. E. Stahlberger, of the Naval Academy, together with an extract from the Journal of Meteorological Observation kept at that Institution, condensing the remarks, \&c., of the original, and omitting such details as are of mere local interest, as well as descriptions of the apparatus used in marking direction.
The year 1870 is not to be taken as a fair specimen of the frequency of earthquakes in this place. It was decidedly an exceptional year, both in this respect and with regard to the weather, which was unusua!ly changeable throughout the whole twelve months, and during the autumn and December was mirked by an abnoimal amount of rain. About the time of the December fullmoon a large halo of broad bands was noticed by our correspondent and others at about 8 P.M. On the 2oth of May, at about 9 P.M., a very faint Aurora Borealis was visible.

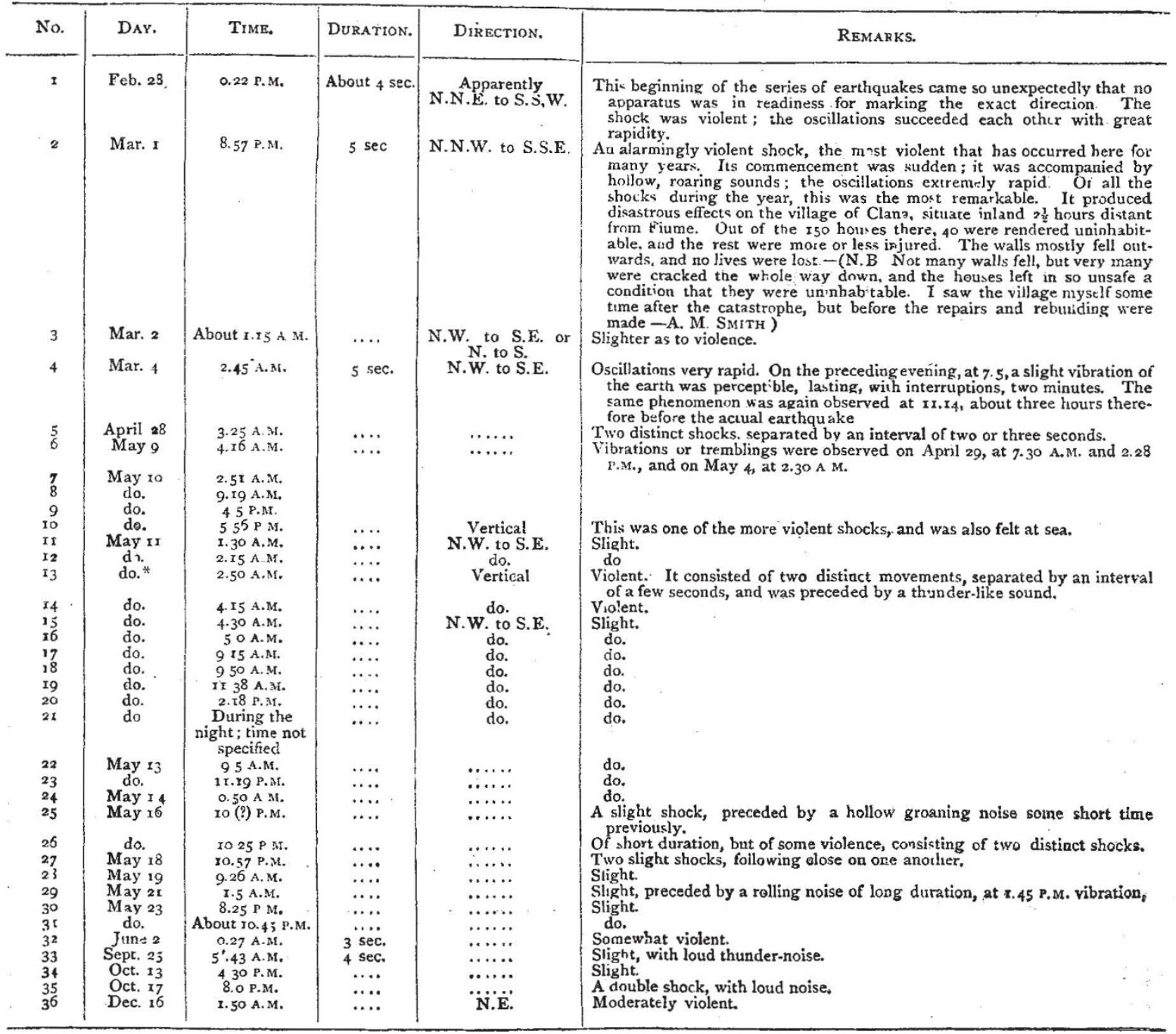

* On this day, between 2.50 and 9.15 A.M., there were 27 insignificant movements not specified in the list.-A. M. S. ? 